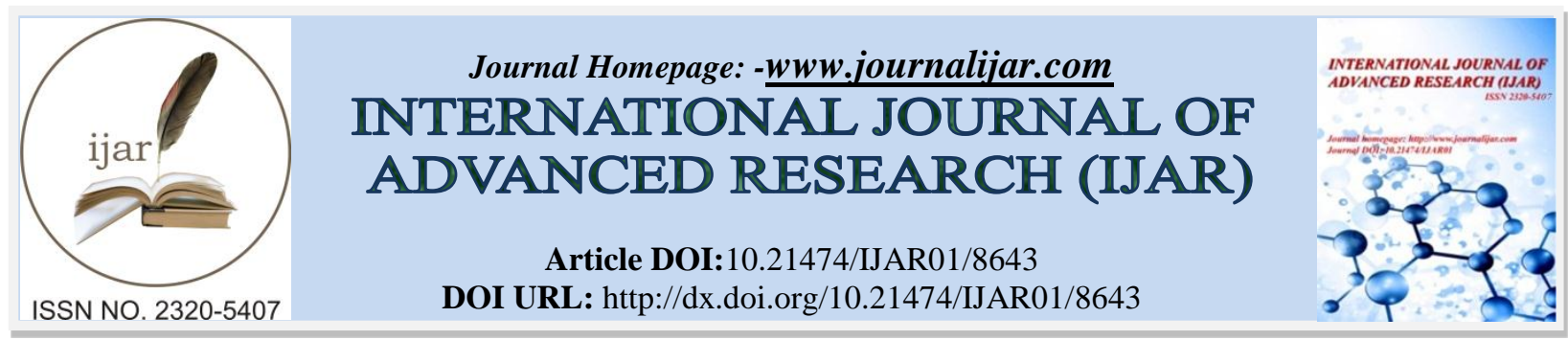

RESEARCH ARTICLE

\title{
EVALUATION OF THE USE OF MEDICINAL HERBS IN THE TREATMENT OF GEOHELMINTHIASIS.
}

Danielle Feijó de Moura ${ }^{1}$, Roberta de Albuquerque Bento da Fonte ${ }^{2}$, Dayane de Melo Barros ${ }^{1}$, Priscilla Gregorio de Oliveira Sousa ${ }^{1}$, Marllyn Marques da Silva ${ }^{1}$, Silvio Assis de Oliveira Ferreira ${ }^{3}$, Gisele Priscilla de Barros Alves Silva ${ }^{4}$, José André Carneiro da Silva ${ }^{4}$, Isla Ariadny Amaral de Souza Gonzaga ${ }^{5}$, Bárbara de Azevedo Ramos ${ }^{6}$, Amanda Virgínia Barbosa ${ }^{6}$ and Tamiris Alves Rocha ${ }^{7}$.

1. Mestre em Saúde Humana e Meio Ambiente - Centro Acadêmico de Vitória, Universidade Federal de Pernambuco, CAV/UFPE - Pernambuco, Brasil.

2. Doutora em Nutrição - Universidade Federal de Pernambuco, UFPE - Pernambuco, Brasil.

3. Mestre em Bioquímica e Fisiologia - Universidade Federal de Pernambuco - Pernambuco, Brasil.

4. Especialista em Saúde Pública - Faculdades Integradas da Vitória de Santo Antão, FAINTVISA - Pernambuco, Brasil.

5. Bacharel em Enfermagem - Centro Acadêmico de Vitória, Universidade Federal de Pernambuco, CAV/UFPEPernambuco, Brasil.

6. Mestre em Ciências Biológicas - Universidade Federal de Pernambuco, UFPE - Pernambuco, Brasil.

7. Doutora em Ciências Biológicas - Universidade Federal de Pernambuco, UFPE - Pernambuco, Brasil.

\section{Manuscript Info}

Manuscript History

Received: 08 January 2019

Final Accepted: 10 February 2019

Published: March 2019

Key words:-

Empirical, geohelminths, helminthiasis, medicinal plants.

\section{Abstract}

Medicinal plants are being used by man both in food and for therapeutic purposes over time. Brazil, it is considered a common practice to. Popular knowledge about the use of medicinal plants has spread among the generations. However, there must be legitimacy of the therapeutic assignments of these plants. Currently, scientific research has proven the medicinal action of plants, through its in natura use or by isolation of its active principle. Among the species that have been highlighted for their therapeutic efficiency are Eucalyptus globulus and Ficus glabrata, which in turn have demonstrated antihemintic action. The helminthiasis are diseases caused by geohelminths, being linked to the absence of basic sanitation and improper habits of hygiene. In this way, the objective of the study was to evaluate the use of medicinal herbs as a form of treatment to the geohelminthiasis. The study was conducted with 28 women in a public school in Pernambuco. The participants answered a questionnaire about the use of medicinal plants in the control of geohelminthiasis. When analyzing the data, it was observed that $50 \%$ of the interviewed women reported using the plants for the treatment of verminoses, and most of them learned to use them with their relatives. Among the plants used are: mastruz, boldo, hortelã and babosa. A significant portion of women grow these plants in their own home. In relation to the ingestion of these plants, the majority consumed in the form of juice. With the obtaining of the data, it was verified that a great part of the interviewees use medicinal plants in the combat to verminoses based on the empirical knowledge.

Copy Right, IJAR, 2019,. All rights reserved. 


\section{Introduction:-}

Over time, plants that have therapeutic properties are being used by man, both in food and for medicinal purposes (ALMASSY JUNIOR et al., 2004). This practice is very common in Brazil, especially in poorer regions (LIMA et al., 2007). Knowledge about plant species that demonstrate medicinal effects is transmitted empirically among generations of the same community, so that it is maintained as a tradition among people (SILVA et al., 2013).

However, it is necessary to have validation of the therapeutic properties of these plants, in case they have beneficial effects, it must also be verified, if the use of the plants considered medicinal can have harmful effects for the health of the man, besides being necessary to realize a investigation of the correct dosages of plants that actually have therapeutic effects (OLIVEIRA et al., 2007).

Scientific research has shown that some species of plants are being recognized for pharmacological use because of their chemical characteristics, since they have potential for the development of herbal medicines (ZUANAZZI and MAYORGA, 2010). Currently several species are being used in natura or by isolating their active principle (SOUZA et al., 2013).

Some of the species that have aroused interest in health research with scientific evidence for its benefits are Eucalyptus globulus commonly used to combat diseases of the respiratory system, in addition to presenting anthelmintic potential (SCHULZ, 2002). Another plant that has been well studied is the Ficus glabrata which, proved to be effective in combating Ascaris lumbricoides (SOUZA et al., 2013).

Helminthiasis are diseases that affect thousands of people worldwide, these diseases are transmitted by helminths of many different species. They are generally related to the absence of sanitation and inadequate hygiene habits, among these diseases, the most common are those caused by the geohelminths as Ascaris lumbricoides, Trichuris trichiura and the hookworms (COSTA-MACEDO, 2007). People who are parasitized by helminths are commonly treated with anthelmintic drugs that are considered safe, effective and inexpensive, however, phytotherapy has been gaining prominence in the treatment of these diseases (AWASTHI et al., 2003). The objective of this study was to conduct research on the use of medicinal herbs as a form of treatment to the geohelminthiasis.

\section{Methodology:-}

The study was conducted with 28 women, mothers of schoolchildren from a public elementary school system in Vitória Santo Antão - Pernambuco, after signing the Written Informed Consent Form (WICF) for persons over 18, resolution 466/2. They answered an interview with questions about the use of medicinal plants in the treatment of helminthiasis. In the interview, some variables were considered, as shown in Table 1.

Table 1.-Variables established for the study

\begin{tabular}{|l|}
\hline \multicolumn{1}{|c|}{ Variables } \\
\hline Degree of schooling \\
\hline Use of plants to combat helminthiasis \\
\hline Medium in which the person learned to use medicinal plants \\
\hline Types of plants they use \\
\hline Form of access to medicinal plants \\
\hline Preparation of the natural remedy \\
\hline
\end{tabular}

The data obtained through the evaluation of the variables will be expressed through graphs.

\section{Results:-}

In analyzing the variables, $28.42 \%$ of the interviewed women were illiterate, $32.15 \%$ read and write, $14.8 \%$ had completed elementary education and $32.15 \%$ had education average full. In the questioning about the use of medicinal plants in combating helminthiasis, 50\% stated that they used them while 50\% refused to use them (Figure 1). Regarding the environment in which people learned to use medicinal plants, $71.43 \%$ said they went through the family and $28.57 \%$ said they learned through friends (Figure 2). The medicinal plants most used for the control of worms were: mastruz (Dysphania ambrosioides), boldo (Peumus boldus), hortelã (Mentha spp.) and babosa (Aloe Vera). In terms of access to medicinal plants, $78.58 \%$ said they cultivate the plants in their own homes, $14.28 \%$ buy them in pharmacies and $7.14 \%$ obtain through the market (Figure 3). And when asked how to prepare the natural remedy, $64.28 \%$ do it as juice and $35.72 \%$ do the preparation in the form of tea (Figure 4). 
Figure 1.-Use of medicinal plants to combat geohelminthiasis

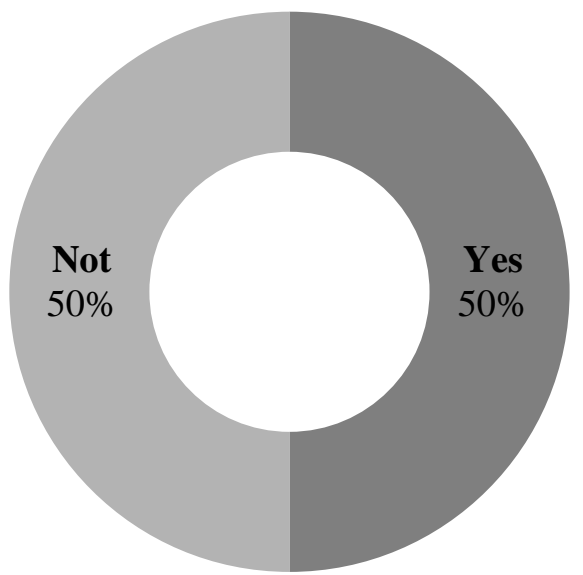

Figure 2.-Medium in which people learned to use medicinal plants

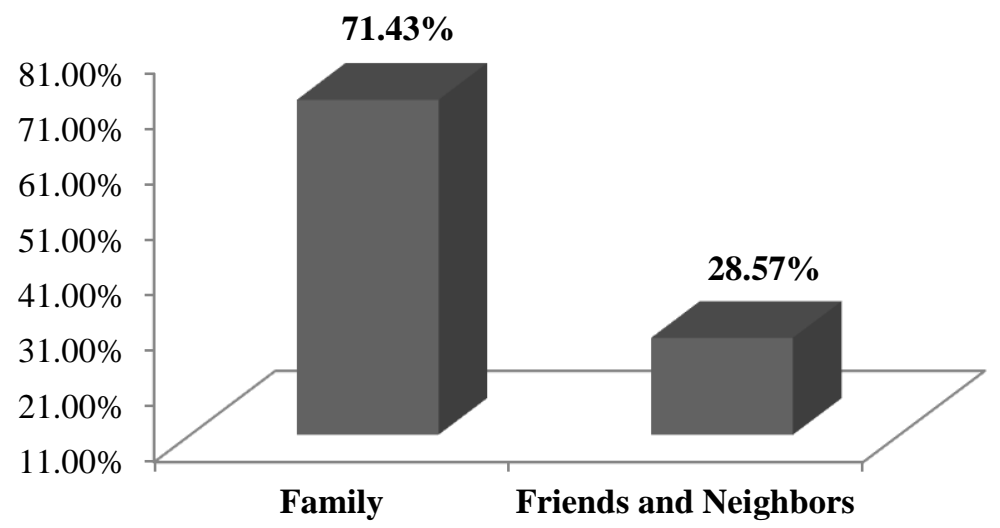

Figure 3.-Form of access to medicinal plants

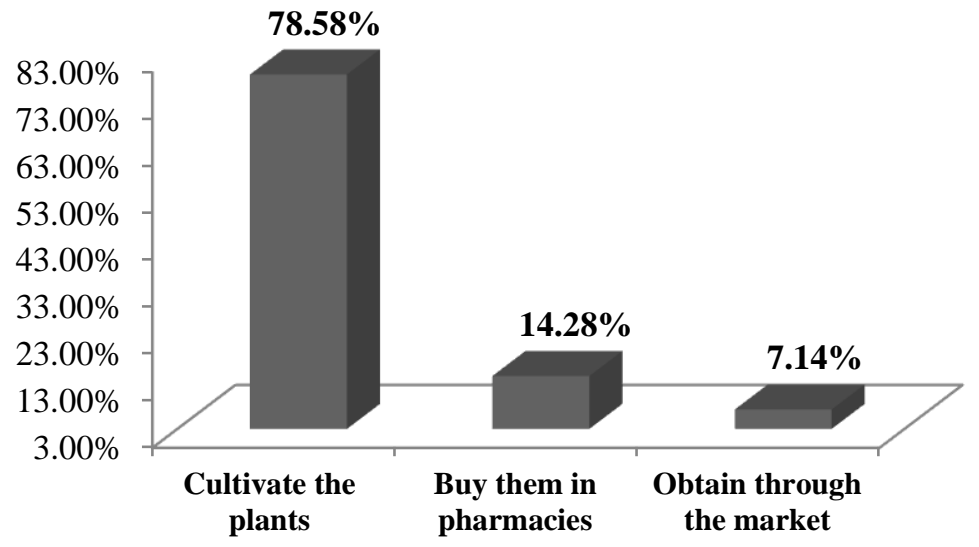


Figure 4.-Preparation of the natural remedy

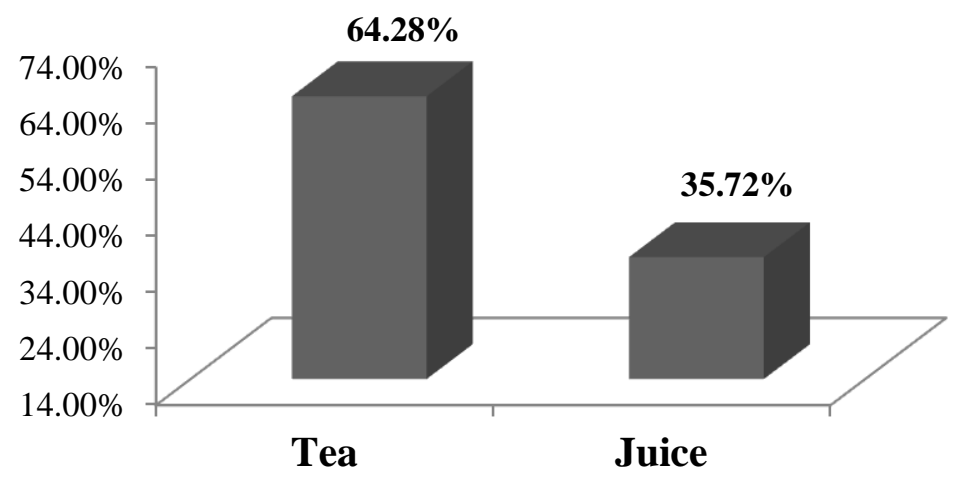

Data were collected concurrently with the study by Turolla and Nascimento (2006) and Firmo et al. (2011) that the use of medicinal plants is based on popular knowledge, where information is disseminated for generations between groups of similar or distinct cultures, usually performed orally, reinforcing a lack of scientific knowledge about the use of plants medicinal products in the fight against verminoses.

\section{Conclusions:-}

With the data collection, it was verified that $50 \%$ of the women interviewed use medicinal plants to combat verminoses based on empirical knowledge, demonstrating a considerable number of people who are adept at the use of natural sources with possible therapeutic action. However, it is important that people are encouraged and properly oriented to use a particular group of herbs that have proven safety and efficacy.

\section{References:-}

1. ALMASSY JUNIOR, A. A. Análise das características etnobotânicas e etnofarmacológicas de plantas medicinais na comunidade de Lavras Novas, ouro Preto/MG. 2004. 132 f. (Doutorado). Universidade Federal de Viçosa, 2004.

2. AWASTHI, S.; BUNDY, D.A.P.; SAVIOLI, L. Helminthic infections. British Medical Journal, v. 327, p. 431 433, 2003.

3. COSTA-MACEDO, L. M. Controle de parasitoses intestinais e ectoparasitoses em instituições de atendimento. Interagir: pensando a extensão, n. 11, p. 21-28. 2007.

4. FIRMO, W.C.A.; MENEZES, V.J.M.; PASSOS, C.E.C.; DIAS, C.L.; ALVES, L.P.L.; DIAS, I.C.L.; NETO, M.S.; OLEA, R.S.G. Contexto histórico, uso popular e concepção científica sobre plantas medicinais. Cad. Pesq., v.18, 2011.

5. LIMA, S. G. V.; LIMA, A. F.; DONAZZOLO, J. L. Resgate do conhecimento popular e uso de plantas medicinais na promoção da saúde em Sananduva - RS. Rev. Bras. Agroecologia, v. 2, n. 1. 2007.

6. OLIVEIRA, C. J.; ARAÚJO, T. L. Plantas medicinais: usos e crenças de idosos portadores de hipertensão arterial. Revista Eletrônica de Enfermagem, v. 9, n. 1, p. 93-105. 2007.

7. SILVA, W.M.O; SOUZA, G.F.X.T.; VIEIRA, P.B.; SANAVRIA, A. Uso popular de plantas medicinais na promoção da saúde animal em assentamentos rurais de Seropédica - RJ. R. bras. Ci. Vet. v. 20, n. 1, p. 32-36. 2013.

8. SOUSA, R.G.; FALCÃO, H.S.; BARBOSA FILHO, J.M.; MELO DINIZ, M.F.F.; BATISTA, L.M. Atividade anti-helmíntica de plantas nativas do continente americano: uma revisão Rev. Bras. Pl. Med. v.15, n.2, p.287292, 2013.

9. Turolla, M.S.; NASCIMENTO, E.S. Informações toxicológicas de alguns fitoterápicos utilizados no Brasil. Revista Brasileira de Ciências Farmacêuticas, v.42, p.289-306, 2006.

10. ZUANAZZI, J.A.S.; MAYORGA, P. Fitoprodutos e desenvolvimento econômico. Química Nova, v. 33, n 6, p. 1421-1428. 